\title{
ANTICONVULSANT POTENCY OF 10 VARIOUS \\ P-ISOPROPOXYPHENYLSUCCINIMIDE DERIVATIVES IN THE MAXIMAL ELECTROSHOCK-INDUCED SEIZURE THRESHOLD MODEL IN MICE
}

\section{PRZECIWDRGAWKOWE DZIAŁANIE 10 RÓŻNYCH POCHODNYCH P-IZOPROPOKSYFENYLOBURSZTYNIMIDÓW W MODELU PROGU MAKSYMALNEGO WSTRZĄSU ELEKTRYCZNEGO U MYSZY}

\author{
Sergey L. Kocharov ${ }^{1(A, D, E)}$, Henry A. Panosyan ${ }^{2(A, D, E)}$, Paweł Marzęda ${ }^{3(B, C, F)}$, \\ Paula Wróblewska-tuczka ${ }^{4(B, C, E, F)}$, Ewelina Kochman ${ }^{3(B, F)}$, Aleksandra Wlaź $^{3(B, E, F)}$, \\ Jarogniew J. Luszczki $\mathbf{i}^{3(\mathrm{~A}, \mathrm{~B}, \mathrm{C}, \mathrm{D}, \mathrm{E}, \mathrm{F}, \mathrm{G})}$
}

${ }^{1}$ A.L. Mnjoyan's Institute of Fine Organic Chemistry, National Academy of Sciences in Yerevan, Armenia

${ }^{2}$ Molecular Structure Research Center, National Academy of Sciences in Yerevan, Armenia

${ }^{3}$ Medical University of Lublin, Poland

${ }^{4}$ Institute of Rural Health in Lublin, Poland

Authors' contribution Wkład autorów: A. Study design/planning zaplanowanie badań B. Data collection/entry zebranie danych C. Data analysis/statistics dane - analiza i statystyki D. Data interpretation E. Preparation of manuscript przygotowanie artykułu wyszukiwanie i analiza literatury G. Funds collection zebranie funduszy interpretacja danych F. Literature analysis/search

\begin{abstract}
Summary
Background. To compare the anticonvulsant potency of 10 various p-isopropoxyphenylsuccinimide (IPPS) derivatives [i.e., IPPS (IPPS); N-(morpholinomethyl)IPPS (MM-IPPS); N-(anilinomethyl)-IPPS (AM-IPPS); N-hydroxymethyl-IPPS (HM-IPPS); $\mathrm{N}$-(p-acetylphenyl)-IPPS (AP-IPPS); N-(p-ethoxycarbonylphenylmethyl)-IPPS (ECPM-IPPS); $\mathrm{N}-(\mathrm{m}$-bromoanilinomethyl)-IPPS (BAM-IPPS); N-(o-carboxyanilinomethyl)-IPPS (o-CAMIPPS); N-(m-carboxyanilinomethyl)-IPPS (m-CAM-IPPS); N-(p-carboxyanilinomethyl)-IPPS (p-CAM-IPPS)] in the maximal electroshock-induced seizure threshold (MEST) test in mice. Material and methods. Linear regression analysis of doses of IPPS derivatives and their threshold increases in the MEST test in mice allowed to calculate TID20 values i.e., doses of the tested IPPS derivatives that elevate by $20 \%$ the seizure threshold in IPPS-treated mice over the threshold in control animals. Results. All the studied IPPS derivatives (i.e.. IPPS, MMIPPS, HM-IPPS, AP-IPPS, AM-IPPS, ECPM-IPPS, o-CAM-IPPS, m-CAM-IPPS, p-CAM-IPPS and BAM-IPPS) increased in a dose dependent manner the threshold for maximal electroshockinduced seizures in mice. The TID20 values in the MEST test for IPPS, AP-IPPS, AM-IPPS, BAMIPPS, o-CAM-IPPS, m-CAM-IPPS, p-CAM-IPPS, ECPM-IPPS, HM-IPPS, and MM-IPPS were 60.44 $\mathrm{mg} / \mathrm{kg}, 86.30 \mathrm{mg} / \mathrm{kg}, 44.69 \mathrm{mg} / \mathrm{kg}, 103.34 \mathrm{mg} / \mathrm{kg}, 22.43 \mathrm{mg} / \mathrm{kg}, 52.84 \mathrm{mg} / \mathrm{kg}, 80.85 \mathrm{mg} / \mathrm{kg}$, $109.75 \mathrm{mg} / \mathrm{kg}, 32.62 \mathrm{mg} / \mathrm{kg}$ and $53.50 \mathrm{mg} / \mathrm{kg}$, respectively. Conclusions. The studied IPPS derivatives with respect to their anticonvulsant potency in the MEST test can be arranged as follows: o-CAM-IPPS > HM-IPPS > AM-IPPS > m-CAM-IPPS > MM-IPPS > IPPS > p-CAM-IPPS > AP-IPPS > BAM-IPPS > ECPM-IPPS.
\end{abstract}

Keywords: p-isopropoxyphenylsuccinimide, electroshock, maximal electroshock-induced seizure threshold, threshold increasing dose by $20 \%$

\section{Streszczenie}

Wprowadzenie. Porównać siłę przeciwdrgawkowego działania 10 różnych pochodnych p-izopropoksyfenylobursztynimidów (IPPS) [tj. (IPPS); N-(morfolinometylo)-IPPS (MM-IPPS); N-(anilinometylo)-IPPS (AM-IPPS); N-hydroksymetylo-IPPS (HM-IPPS); N-(p-acetylofenylo)-IPPS (AP-IPPS); $\mathrm{N}$-(p-etoksykarbonylofenylometylo)-IPPS (ECPM-IPPS); N-(m-bromoanilinometylo)-IPPS (BAM-IPPS); N-(o-karboksyanilinometylo)-IPPS (o-CAM-IPPS); N-(m-karboksyanilinometylo)-IPPS (m-CAM -IPPS); N-(p-karboksyanilinometylo)-IPPS (p-CAM-IPPS)] w teście progu maksymalnego wstrząsu elektrycznego (MEST) u myszy. Materiał i metody. Analiza regresji liniowej dawek pochodnych IPPS i ich wzrostów progu w teście MEST u myszy pozwoliła policzyć wartości TID20 tj. dawki badanych pochodnych IPPS, które podnoszą o $20 \%$ próg drgawkowy u myszy, którym podano IPPS, ponad próg u zwierząt kontrolnych. Wyniki. Wszystkie badane pochodne IPPS (tj. IPPS, MM-IPPS, HM-IPPS, AP-IPPS, AM-IPPS, ECPM-IPPS, o-CAM-IPPS, m-CAM-IPPS, p-CAM-IPPS and BAM-IPPS) zwiększały w sposób zależny od dawki próg maksymalnego wstrząsu elektrycznego u myszy. Wartości TID20 $\mathrm{w}$ teście MEST dla IPPS, AP-IPPS, AM-IPPS, BAM-IPPS, o-CAM-IPPS, m-CAM-IPPS, p-CAM-IPPS, ECPM-IPPS, HM-IPPS i MM-IPPS wynosiły odpowiednio: $60,44 \mathrm{mg} / \mathrm{kg}, 86,30 \mathrm{mg} / \mathrm{kg}$, $44,69 \mathrm{mg} / \mathrm{kg}, 103,34 \mathrm{mg} / \mathrm{kg}, 22,43 \mathrm{mg} / \mathrm{kg}, 52,84 \mathrm{mg} / \mathrm{kg}, 80,85 \mathrm{mg} / \mathrm{kg}, 109,75 \mathrm{mg} / \mathrm{kg}, 32,62 \mathrm{mg} /$ $\mathrm{kg}$ i $53,50 \mathrm{mg} / \mathrm{kg}$. Wnioski. Badane pochodne IPPS w odniesieniu do ich siły przeciwdrgawkowego działania można uporządkować następująco: o-CAM-IPPS > HM-IPPS > AM-IPPS > m-CAM-IPPS > MM-IPPS > IPPS > p-CAM-IPPS > AP-IPPS > BAM-IPPS > ECPM-IPPS.

Słowa kluczowe: p-izopropoksyfenylobursztynimid, wstrząs elektryczny, próg maksymalnego
wstrząsu elektrycznego, dawka zwiększająca próg o $20 \%$

Słowa kluczowe: p-izopropoksyfenylobursztynimid, wstrząs elektryczny, próg maksymalnego
wstrząsu elektrycznego, dawka zwiększająca próg o $20 \%$ Figures: 1

References: 23

Submitted: 2017 Aug 17

Accepted: 2017 Aug 25

Kocharov SL, Panosyan HA, Marzęda P, Wróblewska-Łuczka P, Kochman E, Wlaź A, et al. Anticonvulsant potency of 10 various p-isopropoxyphenylsuccinimide derivatives in the maximal electroshock-induced seizure threshold model in mice. Health Problems of Civilization. 2017; 11(3): 195-201. doi: 10.5114/hpc.2017.70010.

Address for correspondence / Adres korespondencyjny: Jarogniew J. Łuszczki, Medical University of Lublin, Poland, Jaczewskiego 8b, 20-090 Lublin, Poland, e-mail: jarogniew.luszczki@umlub.pl, phone: +48 814486500

Copyright: (C) 2017 Pope John Paul II State School of Higher Education in Biała Podlaska, Sergey L. Kocharov, Henry A. Panosyan, Paweł Marzęda, Paula WróblewskaŁuczka, Ewelina Kochman, Aleksandra Wlaź, Jarogniew J. Łuszczki. This is an Open Access journal, all articles are distributed under the terms of the Creative Commons Attribution-NonCommercial-ShareAlike 4.0 International (CC BY-NC-SA 4.0) License (http://creativecommons.org/licenses/by-nc-sa/4.0/), allowing third parties to copy and redistribute the material in any medium or format and to remix, transform, and build upon the material, provided the original work is properly cited and states its license. 


\section{Introduction}

A large number of publications and articles on the search for new substances possessing anticonvulsant action confirm the fact that treatment of epilepsy is still a topical problem and clinicians today do not possess a sufficient array of highly efficacious drugs devoid of any substantial unfavorable side effects. For this reason, there is an obvious need to search for newer antiepileptic drugs. Up-to-date, several classes of structurally unrelated organic compounds are used in therapy of epilepsy, but they all have certain drawbacks [1].

Despite the structural variety of anticonvulsant substances, some common structural elements responsible for the therapeutic activity have been determined. Such constituents are the nitrogenous heteroatomic system, at least one phenyl ring, and either additional phenyl nucleus or an alkyl substituent attached to the heterocycle [2, 3]. These attributes are, partially or fully, characteristic for a well-established antiepileptic drug - ethosuximide (3-ethyl-3-methyl-pyrrolidine-2,5-dione), which belongs to the succinimide class. However, this class of compounds is not exhausted as a source of new representatives with discussed activity [4-9].

Recently, a significant anticonvulsant activity of 3-(4-isopropoxyphenyl)-pyrrolidine-2,5-dione (3-p-isopropoxyphenylsuccinimide) was observed and this compound was introduced into medical practice in the former Soviet Union [10] under the trade name 'Pufemid'. In view of all the above, it was considered expedient to search for the influence of additional chemical modification of the molecule of 3-p-isopropoxyphenylsuccinimide on its biological properties, namely, on expected changes in the anticonvulsant activity. With this purpose, a series of p-isopropoxyphenylsuccinimide (IPPS) derivatives [i.e., IPPS (IPPS); N-(morpholinomethyl)-IPPS (MM-IPPS); N-(anilinomethyl)-IPPS (AM-IPPS); N-hydroxymethyl-IPPS (HM-IPPS); N-(p-acetylphenyl)-IPPS (AP-IPPS); N-(p-ethoxycarbonylphenylmethyl)-IPPS (ECPM-IPPS); N-(m-bromoanilinomethyl)-IPPS (BAMIPPS); N-(o-carboxyanilinomethyl)-IPPS (o-CAM-IPPS); N-(m-carboxyanilinomethyl)-IPPS (m-CAM-IPPS); $\mathrm{N}$-(p-carboxyanilinomethyl)-IPPS (p-CAM-IPPS)] were tested in an in vivo experimental model of epilepsy - the maximal electroshock-induced seizure threshold (MEST) [11-18]. To unequivocally assess the anticonvulsant potency of the tested candidate drugs in the MEST model, the calculation of TID $_{20}$ value, i.e., doses of the compounds that increase the electroconvulsive threshold by $20 \%$ in drug-treated animals over the threshold in control animals, is recommended [19].

Previously, the anticonvulsant potency of modafinil, its sulfone and acid metabolites and GBR-12909 (a prototypical dopamine transporter blocker) in the MEST test were assessed by calculating the TID $_{20}$ values for these agents [20]. Likewise, the anticonvulsant potency of a series of benzylamide derivatives (i.e., nicotinic acid benzylamide, picolinic acid 2-fluoro-benzylamide, picolinic acid benzylamide, (RS)-methyl-alaninebenzylamide, isonicotinic acid benzylamide and (R)-N-methyl-proline-benzylamide) was assessed in the MEST model by comparing the $\mathrm{TID}_{20}$ values for these compounds in mice [21].

The aim of this study was to calculate the $\mathrm{TID}_{20}$ values for 10 various IPPS derivatives in the MEST test in mice in order to assess their anticonvulsant potency in this seizure model.

\section{Material and methods}

\section{Calculation of TID $_{20}$ values from the MEST test}

Threshold for maximal electroshock-induced seizures was recorded for at least 3 increasing doses of each p-isopropoxyphenylsuccinimide (IPPS) derivative as follows: 25, 50 and $100 \mathrm{mg} / \mathrm{kg}$ for MM-IPPS; 12.5, 25, 50 and $100 \mathrm{mg} / \mathrm{kg}$ for HM-IPPS; 25, 50, 100 and $150 \mathrm{mg} / \mathrm{kg}$ for AP-IPPS; 18.75, 37.5, 75 and $150 \mathrm{mg} / \mathrm{kg}$ for IPPS and AM-IPPS; 50, 100 and $150 \mathrm{mg} / \mathrm{kg}$ for BAM-IPPS and ECPM-IPPS; 37.5, 75 and $150 \mathrm{mg} / \mathrm{kg}$ for o-CAM-IPPS and m-CAM-IPPS; and 75, 100 and $150 \mathrm{mg} / \mathrm{kg}$ for p-CAM-IPPS. Subsequently, the particular doses of IPPS derivatives and their resultant percentage of threshold increase over the threshold for control (vehicle-treated animals) were graphically depicted and examined with linear regression analysis, as recommended earlier [19, 22]. Finally, the $\mathrm{TID}_{20}$ values were directly calculated from linear regression equations.

\section{Results}

\section{TID $_{20}$ values for various IPPS derivatives}

MM-IPPS administered systemically (i.p.) in doses of 25, 50 and $100 \mathrm{mg} / \mathrm{kg}$ increased the threshold for MESTinduced seizures over the threshold for control animals by $10.5 \%, 19.5 \%$ and $34.7 \%$, respectively (Figure $1 \mathrm{~A}$ ). 

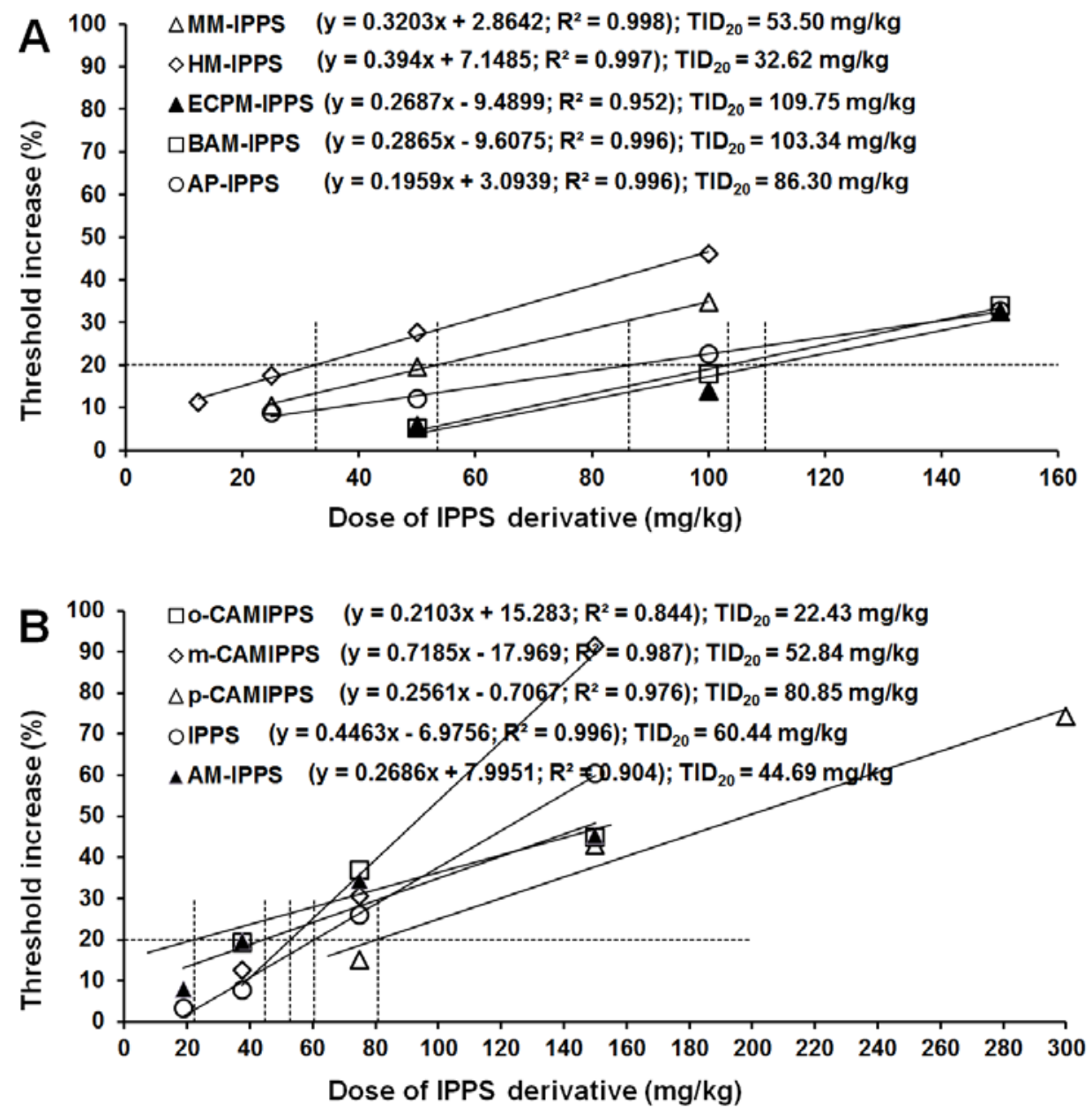

Figure 1A-B. Dose-threshold increase relationship for 10 various IPPS derivatives in the maximal electroshock seizure threshold (MEST) test in mice. Each point corresponds to a threshold increasing dose of IPPS derivative, which was experimentally determined in the MEST test in mice. Linear regression analysis allowed for the determination of equations for dose-threshold increase relationship for 10 IPPS derivatives (Fig. 1A, Fig. 1B). For each IPPS derivative, y-is the threshold increase in $\%, \mathrm{x}$ - is the dose of the studied IPPS derivative, and $\mathrm{R}^{2}$ - coefficient of determination. The dashed line parallel to the abscissa corresponds to the TID $_{20}$ values of IPPS derivatives, (threshold increasing doses by 20\%) in the MEST test

The calculated $\mathrm{TID}_{20}$ value from the linear equation was $53.50 \mathrm{mg} / \mathrm{kg}$ (Figure 1A; Table 1).

Table 1. Comparison of $\mathrm{TID}_{20}$ values for various IPPS derivatives in the MEST test in mice

\begin{tabular}{|l|c|c|c|}
\hline \multicolumn{1}{|c|}{ Chemical name of IPPS derivative } & $\begin{array}{c}\mathrm{TID}_{20} \\
(\mathrm{mg} / \mathrm{kg})\end{array}$ & $\begin{array}{c}\text { Molecular } \\
\text { Weight }\end{array}$ & $\begin{array}{c}\mathrm{TID}_{20} \\
(\mathrm{mM} / \mathrm{kg})\end{array}$ \\
\hline N-(o-Carboxyanilinomethyl)-p-isopropoxyphenylsuccinimide (o-CAM-IPPS) & 22.43 & 382.410 & 0.0587 \\
\hline N-Hydroxymethyl-p-isopropoxyphenylsuccinimide (HM-IPPS) & 32.62 & 263.287 & 0.1239 \\
\hline N-(Anilinomethyl)-p-isopropoxyphenylsuccinimide (AM-IPPS) & 44.69 & 338.400 & 0.1321 \\
\hline N-(m-Carboxyanilinomethyl)-p-isopropoxyphenylsuccinimide (m-CAM-IPPS) & 52.84 & 382.410 & 0.1382 \\
\hline N-(Morpholinomethyl)-p-isopropoxyphenylsuccinimide (MM-IPPS) & 53.50 & 332.390 & 0.1610 \\
\hline p-Isopropoxyphenylsuccinimide monohydrate (IPPS) & 60.44 & 251.277 & 0.2405 \\
\hline N-(p-Carboxyanilinomethyl)-p-isopropoxyphenylsuccinimide (p-CAM-IPPS) & 80.85 & 382.410 & 0.2114 \\
\hline N-(p-Acetylphenyl)-p-isopropoxyphenylsuccinimide (AP-IPPS) & 86.30 & 351.387 & 0.2456 \\
\hline N-(m-Bromoanilinomethyl)-p-isopropoxyphenylsuccinimide (BAM-IPPS) & 103.34 & 417.299 & 0.2476 \\
\hline $\begin{array}{l}\text { N-(p-Ethoxycarbonylphenylmethyl)-p-isopropoxyphenylsuccinimide (ECP- } \\
\text { M-IPPS) }\end{array}$ & 109.75 & 410.460 & 0.2674 \\
\hline
\end{tabular}

Results are doses of the drugs increasing the threshold for maximal electroshock-induced seizures in mice by $20 \%$ ( TID $_{20}$ ) in $\mathrm{mg} / \mathrm{kg}$ and $\mathrm{mM} / \mathrm{kg}$. 
HM-IPPS in doses of 12.5, 25, 50 and $100 \mathrm{mg} / \mathrm{kg}$ elevated the threshold for MEST-induced seizures over the threshold for control animals by $11.2 \%, 17.5 \%, 27.7 \%$ and $46.1 \%$, respectively (Figure $1 \mathrm{~A}$ ). The calculated TID $_{20}$ value was $32.62 \mathrm{mg} / \mathrm{kg}$ (Figure 1A; Table 1).

AP-IPPS injected systemically (i.p.) in doses of 25, 50, 100 and $150 \mathrm{mg} / \mathrm{kg}$ raised the threshold for MESTinduced seizures over the threshold for control animals by $8.8 \%, 12.0 \%, 22.5 \%$ and $32.8 \%$, respectively (Figure 1A). The $\operatorname{TID}_{20}$ value was $86.30 \mathrm{mg} / \mathrm{kg}$ (Figure 1A; Table 1).

BAM-IPPS administered i.p. in doses of 50,100 and $150 \mathrm{mg} / \mathrm{kg}$ elevated the threshold for MEST-induced seizures over the threshold for control animals by 5.3\%,17.9\% and 33.9\%, respectively (Figure $1 \mathrm{~A}$ ). The $\operatorname{TID}_{20}$ value was $103.34 \mathrm{mg} / \mathrm{kg}$ (Figure 1A; Table 1).

ECPM-IPPS administered systemically in the same doses of 50, 100 and $150 \mathrm{mg} / \mathrm{kg}$ increased the threshold for MEST-induced seizures by 5.7\%, 13.9\% and 32.6\%, respectively (Figure 1A). The TID $_{20}$ value was $109.75 \mathrm{mg} /$ kg (Figure 1A; Table 1).

IPPS administered i.p. in doses of 18.75, 37.5, 75 and $150 \mathrm{mg} / \mathrm{kg}$ raised the threshold for MEST-induced seizures over the threshold for control animals by $3.4 \%, 7.8 \%, 26.0 \%$ and $60.5 \%$, respectively (Figure 1B). The $\mathrm{TID}_{20}$ value was $60.44 \mathrm{mg} / \mathrm{kg}$ (Figure 1B; Table 1).

AM-IPPS administered intraperitoneally in the same doses of $18.75,37.5,75$ and $150 \mathrm{mg} / \mathrm{kg}$ elevated the threshold for MEST-induced seizures by 8.0\%, 19.8\%, 34.5\% and 45.3\%, respectively (Figure 1B). The TID $_{20}$ value was $44.69 \mathrm{mg} / \mathrm{kg}$ (Figure 1B; Table 1).

o-CAM-IPPS injected systemically (i.p.) in doses of 37.5, 75 and $150 \mathrm{mg} / \mathrm{kg}$ elevated the threshold for MESTinduced seizures over the threshold for control animals by $19.3 \%, 36.9 \%$ and $44.9 \%$, respectively (Figure 1B). The $\mathrm{TID}_{20}$ value for o-CAM-IPPS was $22.43 \mathrm{mg} / \mathrm{kg}$ (Figure 1B; Table 1).

m-CAM-IPPS administered i.p. in the same doses of 37.5, 75 and $150 \mathrm{mg} / \mathrm{kg}$ increased the threshold for MESTinduced seizures by $12.5 \%, 30.6 \%$ and $91.6 \%$ over the threshold for control animals, respectively (Figure 1B). The $\mathrm{TID}_{20}$ value was $52.84 \mathrm{mg} / \mathrm{kg}$ (Figure 1B; Table 1).

The last tested IPPS derivative, p-CAM-IPPS, when injected i.p. in the doses of 75, 150 and $300 \mathrm{mg} / \mathrm{kg}$ raised the threshold for MEST-induced seizures by $15.0 \%, 42.93 \%$ and $74.4 \%$ over the threshold for control animals, respectively (Figure 1B). The $\mathrm{TID}_{20}$ value was $80.85 \mathrm{mg} / \mathrm{kg}$ (Figure 1B; Table 1).

\section{Discussion}

The main goal of this study was to compare the anticonvulsant properties of a series of IPPS derivatives and classify the compounds taking into account their anticonvulsant potency manifesting in elevation of the threshold for maximal electroshock-induced seizures in mice. In this study, we did not examine the anticonvulsant effects of various IPPS derivatives in the MEST test, but we only calculated the $\operatorname{TID}_{20}$ values from the antiseizure effects that have already been determined in our earlier studies. A novelty of our research is related to the determination of the anticonvulsant potency of 10 IPPS derivatives by calculating their TID $_{20}$ values in the MEST test, which allowed us to compare the anticonvulsant potency of the tested IPPS derivatives. In the MEST test, researchers usually determine the threshold for maximal electroshock-induced seizures in mice receiving various doses of the examined compounds. Unfortunately, the threshold for control (vehicle-treated) animals differs in each day of experiment in the MEST test, therefore, researchers cannot directly compare the anticonvulsant effects produced by various compounds. Also classification of the compounds with respect to their antiseizure potency is impossible. To be able to compare the effects produced by various compounds in the MEST test, the calculation of TID $_{20}$ values is recommended [22]. Sometimes researchers calculate TID $_{50}$ values, i.e., doses of the compounds elevating the threshold by $50 \%$ as compared to the threshold value for control animals, but such calculations are very rare. To calculate the $\mathrm{TID}_{20}$ values for IPPS derivatives, we used linear regression analysis, which analyzed the increasing doses of 10 IPPS derivatives and their corresponding threshold increases in mice challenged with the MEST test. It is important to note that the $\operatorname{TID}_{20}$ values as determined in the MEST test are substantially lower than the experimentally determined $\mathrm{ED}_{50}$ values in the MES test [11-18]. Furthermore, we have reported that some of the studied IPPS derivatives when combined with classical antiepileptic drugs, they potentiated the anticonvulsant properties of the selected antiepileptic drugs (i.e., phenytoin, phenobarbital and valproate) in the mouse MES model in mice [11,13-18]. More specifically, it has been found that AM-IPPS, AP-IPPS, HM-IPPS and MM-IPPS significantly potentiated the antiseizure activity of phenobarbital and valproate in the mouse MES model (Table 2). 
Table 2. Influence of various IPPS derivatives on the anticonvulsant potency of classical antiepileptic drugs in the MES test in mice

\begin{tabular}{|c|c|c|c|c|c|}
\hline \multirow{2}{*}{ IPPS derivative } & \multicolumn{4}{|c|}{ Classical antiepileptic drugs } & \multirow{2}{*}{ References } \\
\hline & Carbamazepine & Phenytoin & Phenobarbital & Valproate & \\
\hline AM-IPPS & 0 & 0 & $\uparrow$ & $\uparrow$ & {$[14]$} \\
\hline AP-IPPS & 0 & 0 & $\uparrow$ & $\uparrow$ & {$[16]$} \\
\hline BAM-IPPS & 0 & 0 & 0 & 0 & [17] \\
\hline o-CAM-IPPS & $\downarrow$ & 0 & 0 & 0 & {$[12]$} \\
\hline m-CAM-IPPS & 0 & 0 & 0 & 0 & {$[12]$} \\
\hline p-CAM-IPPS & 0 & 0 & 0 & 0 & {$[12]$} \\
\hline ECPM-IPPS & 0 & 0 & 0 & 0 & [11] \\
\hline HM-IPPS & 0 & 0 & $\uparrow$ & $\uparrow$ & [15] \\
\hline IPPS & 0 & $\uparrow$ & 0 & $\uparrow$ & {$[13]$} \\
\hline MM-IPPS & 0 & 0 & $\uparrow$ & $\uparrow$ & [18] \\
\hline
\end{tabular}

$\uparrow$ - increase in the anticonvulsant potency;

0 - no significant effect on the anticonvulsant potency;

$\downarrow$-decrease in the anticonvulsant potency.

Likewise, IPPS enhanced the anticonvulsant action of phenytoin and valproate in mice challenged with the MES test. In contrast, o-CAM-IPPS significantly reduced the anticonvulsant action of carbamazepine in the MES test in mice (Table 2). Only, BAM-IPPS, m-CAM-IPPS, p-CAM-IPPS and ECPM-IPPS had no significant impact on the anticonvulsant properties of all the tested classical antiepileptic drugs in the MES test in mice (Table 2).

On the other hand, it should be mentioned that IPPS derivatives tested in this study at doses reflecting their $\mathrm{TID}_{20}$ values did not produce any acute adverse effects in mice. More specifically, no significant impairment of motor coordination (ataxia) or alleviation of skeletal muscular strength (flaccidity) were reported in mice [1118]. In other words, lack of any adverse effects associated with the treatment with IPPS derivatives contributes to their favorable pharmacological profiles in preclinical studies. Of note, in preclinical epileptology, researchers are obliged to indicate which of the tested compounds is the most favorable with respect to their suppression of seizures. Considering the calculated TID $_{20}$ values for IPPS derivatives, the most favorable compound was o-CAMIPPS with the lowest TID $_{20}$ value of $22.43 \mathrm{mg} / \mathrm{kg}$.

Additional explanations are required when discussing facts that some IPPS derivatives potentiated the anticonvulsant action of phenobarbital and valproate, whose main anticonvulsant action is associated with activation of GABA-ergic neurotransmission in the brain [23]. In contrast, IPPS derivatives did not enhance the anticonvulsant action of carbamazepine and phenytoin (except for IPPS), whose main anticonvulsant effects are mediated by the blockade of voltage-dependent sodium channels in neurons [23]. It can be suggested that IPPS derivatives can possess similar molecular mechanisms of action to those of carbamazepine and phenytoin. In such a situation, IPPS derivatives probably compete carbamazepine and phenytoin to bind to their target sites. This hypothesis can be confirmed at least partially by an observation of the effects of o-CAM-IPPS with carbamazepine in the mouse MES test. It was found that o-CAM-IPPS alleviated the anticonvulsant action of carbamazepine in mice. In contrast, two structurally similar IPPS derivatives (m-CAM-IPPS and p-CAM-IPPS) had no impact on the anticonvulsant action of carbamazepine in the mouse MES test in mice. It can be suggested that o-CAM-IPPS blocks specific binding of carbamazepine to its target in neurons and, in consequence, it reduced the antiseizure effects of the drug. Additionally, as documented in this study, all three CAM-IPPS derivatives (o-CAM-IPPS, m-CAM-IPPS and p-CAM-IPPS), despite almost identical chemical structure, had diverse TID $_{20}$ values, ranging from $22.43 \mathrm{mg} / \mathrm{kg}$ (o-CAM-IPPS), $52.84 \mathrm{mg} / \mathrm{kg}$ (m-CAM-IPPS) to $80.85 \mathrm{mg} / \mathrm{kg}$ (p-CAM-IPPS). Of note, the TID $_{20}$ value for p-CAM-IPPS was 3.6-times higher than that for o-CAM-IPPS (Table 1).

In this study we arranged the IPPS derivatives with respect to their anticonvulsant properties observed in the MEST test in mice. As shown in Table 1, the strongest anticonvulsant properties possessed o-CAM-IPPS with its TID $_{20}$ value of $22.43 \mathrm{mg} / \mathrm{kg}$, whereas the weakest properties were documented for ECPM-IPPS with its $\mathrm{TID}_{20}$ value of $109.75 \mathrm{mg} / \mathrm{kg}$ (Table 1). Undoubtedly, our classification allowed to indicate the most beneficial IPPS derivatives, which were characterized by strong anticonvulsant effects (low $\mathrm{TID}_{20}$ values) and lack of any adverse effects in experimental animals.

In conclusion, the compared IPPS derivatives with respect to their anticonvulsant potency in the MEST test can be arranged in ascending order as follows: o-CAM-IPPS > HM-IPPS > AM-IPPS > m-CAM-IPPS > MM-IPPS > IPPS > p-CAM-IPPS > AP-IPPS > BAM-IPPS > ECPM-IPPS. 


\section{References:}

1. Lason W, Dudra-Jastrzebska M, Rejdak K, Czuczwar SJ. Basic mechanisms of antiepileptic drugs and their pharmacokinetic/pharmacodynamic interactions: an update. Pharmacol Rep. 2011; 63: 271-292.

2. Chimirri A, De Sarro A, De Sarro G, Grasso S, Trimarchi GR, Zappala M. Synthesis and anticonvulsant properties of 2,3,3a,4-tetrahydro-1H-pyrrolo[1,2-a]benzimidazol-1-ones. J Med Chem. 1989; 32: 93-95.

3. Wong MG, Defina JA, Andrews PR. Conformational analysis of clinically active anticonvulsant drugs. J Med Chem. 1986; 29: 562-572.

4. Chmielewska B. Anticonvulsant action of new cyclic derivatives of phenylsuccinimides. Pharmazie. 1983; 38: 872-873.

5. Chmielewska B. Pharmacological properties of new cyclic derivatives of phenylsuccinimide and their influence on noradrenaline, dopamine, serotonin, 5-hydroxyindoleacetic acid, gamma-aminobutyric acid concentrations and monoaminooxidase activity in animal brains. Pharmazie. 1984; 39: 259-262.

6. Edafiogho IO, Scott KR, Moore JA, Farrar VA, Nicholson JM. Synthesis and anticonvulsant activity of imidooxy derivatives. J Med Chem. 1991; 34: 387-392.

7. Kaminski K, Obniska J. Design, synthesis, and anticonvulsant activity of N-phenylamino derivatives of 3,3-dialkyl-pyrrolidine-2,5-diones and hexahydro-isoindole-1,3-diones. Bioorg Med Chem. 2008; 16: 492131.

8. Kaminski K, Obniska J, Dybala M. Synthesis, physicochemical and anticonvulsant properties of new $\mathrm{N}$-phenylamino derivatives of 2-azaspiro[4.4]nonane- and [4.5]decane-1,3-diones: part V. Eur J Med Chem. 2008; 43: 53-61.

9. Owoyale JA, Lahan GD, Osuide G, Edafiogho IO. Succinimides with oxyacetate side chain as potential anticonvulsant agents. J Pharm Sci. 1981; 70: 963.

10. Mndzhoyan OL, Avetisyan SA, Akopyan NE, Gerasimyan DA, Dzhagatspanyan IA, Pashinyan SA. Pufemide a new USSR antiepileptic drug. Pharm Chem J. 1983; 17: 452-455.

11. Luszczki J, Marzęda E, Kondrat-Wróbel M, Wróbel J, Kocharov SL, Florek-Łuszczki M. Effect of N-(pethoxycarbonylphenylmethyl) -p-isopropoxyphenylsuccinimide on the anticonvulsant action of four classical antiepileptic drugs in the mouse maximal electroshock-induced seizure model. J Pre-Clin Clin Res. 2014; 8: 34-37.

12. Luszczki JJ, Cioczek JD, Kocharov SL, Andres-Mach M, Kominek M, Zolkowska D. Effects of three $\mathrm{N}$-(carboxyanilinomethyl) derivatives of p-isopropoxyphenylsuccinimide on the anticonvulsant action of carbamazepine, phenobarbital, phenytoin and valproate in the mouse maximal electroshock-induced seizure model. Eur J Pharmacol. 2010; 648: 74-79.

13. Luszczki JJ, Kocharov SL, Czuczwar SJ. Effect of p-isopropoxyphenylsuccinimide monohydrate on the anticonvulsant action of carbamazepine, phenobarbital, phenytoin and valproate in the mouse maximal electroshock-induced seizure model. Pharmacol Rep. 2010; 62: 194-202.

14. Luszczki JJ, Kocharov SL, Czuczwar SJ. N-(anilinomethyl)-p-isopropoxyphenylsuccinimide potentiates the anticonvulsant action of phenobarbital and valproate in the mouse maximal electroshock-induced seizure model. Neurosci Res. 2009; 64: 267-272.

15. Luszczki JJ, Kominek M, Florek-Luszczki M, Tchaytchian DA, Kocharov SL, Zolkowska D. Influence of N-hydroxymethyl-p-isopropoxyphenylsuccinimide on the anticonvulsant action of different classical antiepileptic drugs in the mouse maximal electroshock-induced seizure model. Epilepsy Res. 2012; 100: 2736.

16. Łuszczki JJ, Kominek M, Marzęda E, Durmowicz D, Florek-Łuszczki M, Kocharov SL. Influence of N-(pacetylphenyl)-p-isopropoxyphenylsuccinimide on the protective action of classical antiepileptic drugs against maximal electroshock-induced seizures in mice. Curr Issues Pharm Med Sci. 2013; 26: 76-81.

17. Luszczki JJ, Marzeda E, Kondrat-Wrobel MW, Pyrka D, Kocharov SL, Florek-Luszczki M. Effect of N-(mbromoanilinomethyl)-p-isopropoxyphenylsuccinimide on the anticonvulsant action of four classical antiepileptic drugs in the mouse maximal electroshock-induced seizure model. Curr Issues Pharm Med Sci. 2014; $27: 76-79$.

18. Zolkowska D, Kominek M, Florek-Luszczki M, Kocharov SL, Luszczki JJ. Effects of N-(morpholinomethyl)p-isopropoxyphenylsuccinimide on the protective action of different classical antiepileptic drugs against maximal electroshock-induced tonic seizures in mice. Pharmacol Rep. 2013; 65: 389-398.

19. Swinyard EA, Brown WC, Goodman LS. Comparative assays of antiepileptic drugs in mice and rats. J Pharmacol Exp Ther. 1952; 106: 319-330.

20. Zolkowska D, Andres-Mach M, Prisinzano TE, Baumann MH, Luszczki JJ. Modafinil and its metabolites enhance the anticonvulsant action of classical antiepileptic drugs in the mouse maximal electroshock- 
induced seizure model. Psychopharmacology. 2015; 232: 2463-2479.

21. Swiader MJ, Paruszewski R, Luszczki JJ. Assessment of the anticonvulsant potency of various benzylamide derivatives in the mouse maximal electroshock-induced seizure threshold model. Pharmacol Rep. 2016; 68: 259-262.

22. Loscher W, Fassbender CP, Nolting B. The role of technical, biological and pharmacological factors in the laboratory evaluation of anticonvulsant drugs. II. Maximal electroshock seizure models. Epilepsy Res. 1991; 8: 79-94.

23. Czapinski P, Blaszczyk B, Czuczwar SJ. Mechanisms of action of antiepileptic drugs. Curr Top Med Chem. 2005; 5: 3-14. 